\title{
EFFECT OF BIOSTIMULANTS ON SOME BIOACTIVE COMPOUNDS AND NITRATE LEVEL IN LETTUCE (Lactuca sativa L.) GROWN UNDER UNHEATED PLASTIC TUNNEL
}

\author{
A.A. Yaseen ${ }^{1,2} \quad$ M. T.-Hajos ${ }^{1}$ \\ Researcher \\ Researcher \\ ${ }^{1}$ University of Debrecen, Faculty of Agricultural and Food Sciences and Environmental Management, \\ Institute of Horticultural Science \\ H-4032 Debrecen, Böszörményi Street 138. \\ ${ }^{2}$ Salahaddin University-Erbil, College of Agricultural Engineering Sciences, Department of \\ Horticulture, Kurdistan Region, Iraq \\ E-mail: arshad.yaseen@agr.unideb.hu
}

\begin{abstract}
Based on the regulation (EU) No 2015/1107 in 8 July 2015, Willow (Salix alba) bark extract is a recent approved basic substance in Europe as a safe and effective environmentally friendly fungicide to be used in plant protection. Because of having indole butyric acid content, it is also used as a growth hormone to promote rooting in cutting propagation of wooden part in horticultural plants. This research aimed to evaluate the effect of willow extract and Ferbanat $\mathrm{L}$ (Bistep) on lettuce leaves. Bistep is an organic solution of nano fertilizer which is produced in Hungary and allowed as „Bistep plant conditioner”. Furthermore, the experiment evaluated their interaction on some bioactive compounds in different lettuce varieties, too. Three different lettuce varieties (King of May, Kobak and Great Lakes) were evaluated for total polyphenols, vitamin C and nitrate content in fresh leaves. The results indicate that the contents were significantly affected by the used biostimulants rather than varieties. Significantly difference of the total polyphenols was recorded in the plants treated with Willow + Bistep (80.64 mg GAE / 100g) in comparison to the control (55.85 mg GAE / 100g) in the mean of varieties. Similar result was recorded for the vitamin $C$. However, plants treated with Willow extract resulted in the highest level of nitrate content $(692.00 \mathrm{mg} / 100 \mathrm{~g})$, while the lowest amount was measured in the control $(488.00$ $\mathrm{mg} / \mathbf{1 0 0 g}$ ). According to our results, Willow bark extract can be a beneficial source of natural growth regulator or fungicide; however, when it is used alone for vegetables, the nutrient content (mainly nitrate level) must be checked before consuming and delivering to the market.
\end{abstract}

Keywords: Willow bark extract, Ferbanat L (Bistep), biostimulants, total polyphenol content, nitrate content, lettuce (Lactuca sativa Linn).

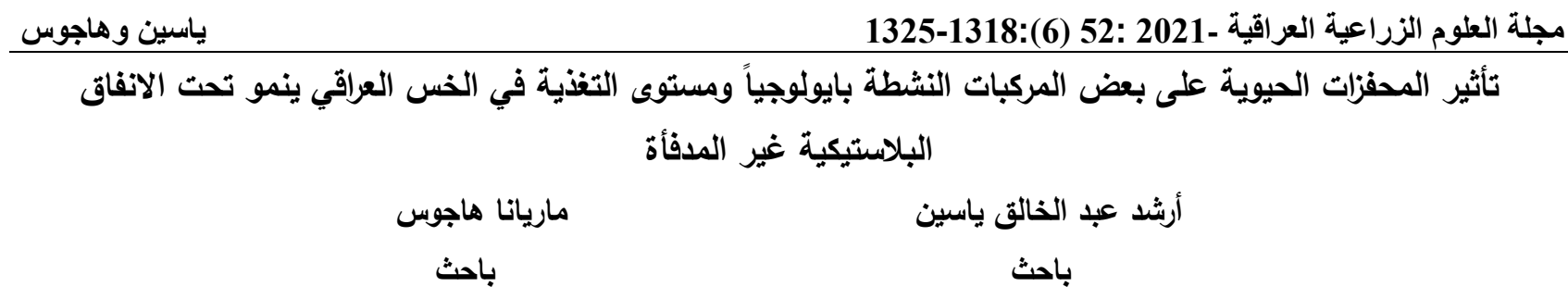

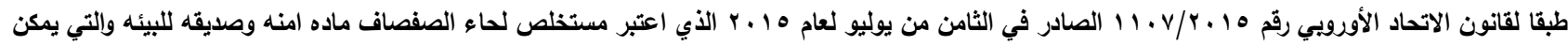

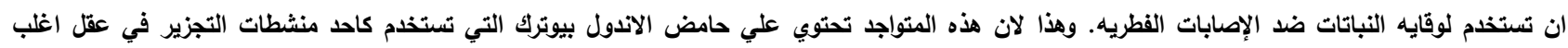

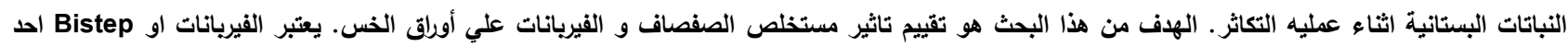

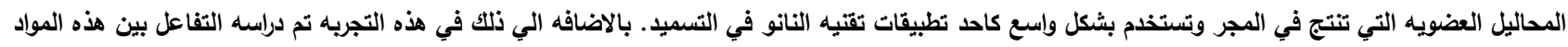

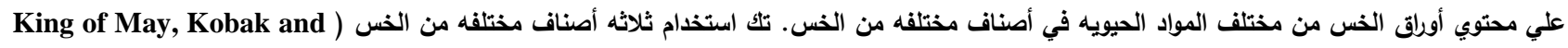

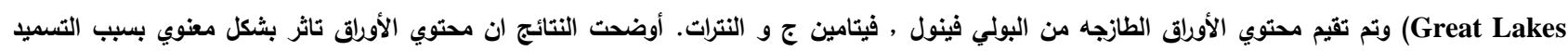

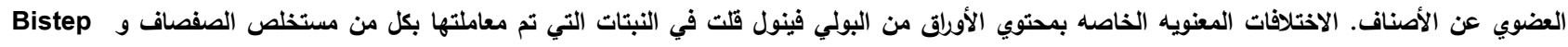

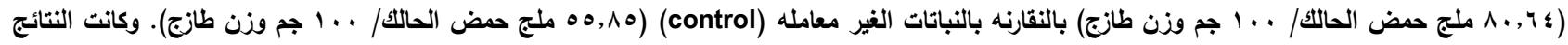

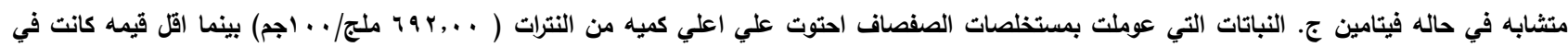

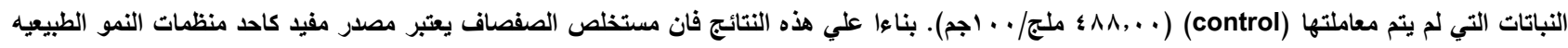
وأيضا مضادات الفطريات ولكن اذا تم استخدامه مع الخضروات الورقيه لابد قبل الاستخدام ان يتم قياس نسبه النترات فيها قبل وصولها لتها للأسواق. الكلمات المفتاحية: مستخلص لحاء الصفصاف, فيربانات, المنشطات العضويه, البولي فينول, النترات, الخس 


\section{INTRODUCTION}

Vegetables and fruit are the main source of bioactive compounds such as polyphenols, carotenoids, vitamins and fibre that human can get benefit from it to improve the immune system of the body $(14,32)$. These materials and antioxidants can prevent human health from chronic diseases, heart attack, cancer and aging processes $(26,47)$. Due to the health benefits of fruit and vegetables and their possible role in the biological activities in the body, the daily intake of at least $400 \mathrm{~g}$ of nonstarchy vegetables and fruit have been recommended by the World Health Organization (50). Vegetables are unique for nutrient supply; they need a high amount of fertilizer during their growing season. However, excessive fertilizing may lead to reverse its benefits of the plants and cause quality losses by nitrate accumulation. Lettuce and spinach are among the richest nitrate sources in the leafy vegetable groups and have the characteristics of nitrate accumulation in their leaves $(27,40)$. According to the EU regulation, there is a limited allowed level for nitrate content in the leafy vegetables which must be evaluated before sending to the markets (13). Sometimes there is difference in the regulation between the countries (7). The acceptable daily intake (ADI) of nitrate of 3.7 $\mathrm{mg} / \mathrm{kg}$ body weight/day is recommended, for example, a person with a body weight of $75 \mathrm{~kg}$ can only take a maximum of $277 \mathrm{mg}$ of nitrate or $0-0.37 \mathrm{mg} \mathrm{kg}^{-1}$ of body weight $(5,8)$. Few minutes after consuming fresh vegetables, a part of the inorganic nitrate content (around $5 \%$ ) is converted to nitrite in the mouth through salvia bacteria, thus this may cause serious health problems to the human body $(7,25,24)$. The risk of the high body exposure to nitrite is converting hemoglobin to methemoglobin by oxidizing heme $\mathrm{Fe}^{2+}$ to $\mathrm{Fe}^{3+}$, which leads to a lack of oxygen transportation in the blood $(9,38)$. Depending on the daily intake and age, nitrate can be either beneficial or harmful to the human body (15). Nitrate is useful for protecting the intestine from some bacterial infections when it is consumed in normal amount $(4,34)$. Nitrate is mostly found in drinking water, meat products and vegetables. Some studies have connected the risk of taking high nitrate level to the stomach cancer (44), others believe that there is no positive relationship between vegetable nitrate and gastric cancer $(19,20)$. Therefore, it is suggested to avoid continuously exceeded ADI range uptake nitrate in the sources with high level of nitrate contents such as drinking water (derived from surface water), cheese added nitrate, and some leafy vegetables (8). Nitrate content in vegetables is varied from plant genotype to another even between spices and cultivars (9). Many organic substances as manures and biostimulants have been confirmed as an alternative to chemical fertilizer which are used as a source of nutrient to improve the plant quality and reduction of nitrate in plants (28-30). Biostimulants alone or with other extracts can improve vigour, quality and yield of many plants $(45,17)$. Salix alba bark extract has recently been registered in the EU to protect plants in organic farming as a fungicide mainly in the protection of arboriculture and viticulture (12). The willow bark extract is used for multiple agricultural purposes as plant growth regulator in cutting propagation since it contains indole butyric acid and as a safe fungicide against variety of fungal disease such as Plasmopara viticola (downy mildews) and Erysiphe necator (powdery mildews) in grapevines, scab disease (Venturia inaequalis), powdery mildews in apple trees (Podosphaera leucotricha), and foliar fungi like Taphrina deformans in peach trees (34-36). The extract has not been approved yet for all the vegetables and fruit, however, some suggestions and research work on tomatoes, berries and kiwi have been submitted for further evaluation to the EU (18). The aim of this study is to determine the side effect or changes in some quality parameters as bioactive compounds and nitrate content in lettuce leaves while using the willow extract, Bistep and both together as a plant growth regulator on lettuce.

\section{MATERIAIS AND METHODS}

Willow bark extract preparation The Willow bark extract was prepared from an old Salix alba tree at the Agrar Campus, University of Debrecen, Hungary. We used the method developed by Marchand (36), in this way $100 \mathrm{~g}$ of newly grown (one year old) tree branches were chopped to $2.5-3 \mathrm{~cm}$ and placed in warm 
tap water at $80^{\circ} \mathrm{C}$ and left to cool down then kept for 24 hours at room temperature. Later on, the liquid was filtered to separate the extract and diluted to $5 \%$ for the experimental usages. The amount remained was kept in the refrigerator until it is treated to the plants for the following occasions. The extract was analyzed in the lab which results are shown in Table 1.

Table 1. The chemical content of the Willow bark extract

\begin{tabular}{|lc|}
\hline Elements & Willow extract \\
\hline pH & 7.22 \\
Nitrate $\left(\mathrm{NO}_{3}{ }^{-}\right)(\mathrm{mg} / \mathrm{l})$ & $<\mathbf{0 , 2 0 0}$ \\
Phosphorus $\left(\mathrm{P}_{2} \mathrm{O}_{5}\right)(\mathrm{mg} / \mathrm{l})$ & 78.8 \\
Potassium oxide $\left(\mathrm{K}_{2} \mathrm{O}\right)(\mathrm{mg} / \mathrm{l})$ & 235 \\
Magnesium $(\mathrm{Mg})(\mathrm{mg} / \mathrm{l})$ & 6.02 \\
Manganese $(\mathrm{Mn})(\mathrm{mg} / \mathrm{l})$ & $\mathbf{0 . 3 8 6}$ \\
Zinc $(\mathrm{Zn})(\mathrm{mg} / \mathrm{l})$ & $\mathbf{0 . 0 6 9}$ \\
Sodium $(\mathrm{Na})(\mathrm{mg} / \mathrm{l})$ & 14.7 \\
Sulphur $\left.(\mathrm{SO})_{2}\right)(\mathrm{mg} / \mathrm{l})$ & $\mathbf{5 . 2 1}$ \\
Copper $(\mathrm{Cu})(\mathrm{mg} / \mathrm{l})$ & $\mathbf{0 . 1 5 8}$ \\
\hline
\end{tabular}

Plants was treated the extract once per two weeks with the amount of $50 \mathrm{ml} / \mathrm{plant}$ through irrigation as follows:

Control plants: treated with distilled water only.

Willow extract: plants irrigated with 50 $\mathrm{ml} /$ plant of Willow extract $(5 \%)$ every two weeks for three times interval.

Bistep: plants sprayed with Ferbanat L (Bistep) (0.5\%) with the mount of $20 \mathrm{ml} /$ plant once per two weeks from transplanting.

Bistep + Willow: plants treated with Bistep+Willow extract with the concentrations of $0.5 \%$ of $(20 \mathrm{ml} / \mathrm{plant})$ Bistep and $5 \%$ of Willow bark extract $(50 \mathrm{ml} /$ plant $)$ at the same time, once per two weeks from transplanting.

\section{Ferbanat L (Bistep) preparation}

Ferbanat $L$ is an organic nano fertilizer solution which is produced in Hungary by a Turkish Ekosistem company. It is allowed as „Bistep plant conditioner” (46). As it was recommended by the company producer, the solution was prepared with the concentration of $0.5 \%$ and directly sprayed onto the plant leaves. The composition of the product is shown in Table 2.
Table 2. Ferbanat L (Bistep) mineral content

\begin{tabular}{|c|c|}
\hline Elements & Bisteps \\
\hline pH & 7.4 \\
\hline Nitrate $\left(\mathrm{NO}_{3}{ }^{-}\right)(\mathrm{mg} / \mathrm{l})$ & 0.02 \\
\hline Phosphorus $\left(\mathrm{P}_{2} \mathrm{O}_{5}\right)(\mathrm{mg} / \mathrm{l})$ & 0.03 \\
\hline Potassium oxide $\left(\mathrm{K}_{2} \mathrm{O}\right)(\mathrm{mg} / \mathrm{l})$ & 0.3 \\
\hline Magnesium (Mg) (mg/l) & 0.02 \\
\hline Manganese (Mn) (mg/l) & 0.007 \\
\hline Zinc (Zn) (mg/l) & 0.008 \\
\hline Molybdenum (Mo) (mg/l) & 0.09 \\
\hline Organic material $(\mathrm{m} / \mathrm{m} \%)$ & 25.0 \\
\hline Iron (Fe) (mg/l) & 0.01 \\
\hline Boron (B) (mg/l) & 0.0002 \\
\hline Total number of germs (number $/ \mathrm{cm}^{2}$ ) & $0.810^{7}$ \\
\hline Micro fungus (number/cm²) & $1.0 \times 10^{2}$ \\
\hline
\end{tabular}

Seeds of three different varieties King of May, Kobak and Great Lakes was sown in a plastic tray under optimum conditions until they reach to 4 true leaves. After about 35 days of sowing, the seedlings were transplanted to unheated plastic tunnel on March 20 2019. Two weeks later, the plants were treated with the biostimulants with the above given concentration. Harvest was 72 days after planting. The whole heads of the lettuce plants were cut. For the sample preparation was used outer, middle and inner leaves of each plant in different treatment and variety combination.

Determination of total polyphenol content Total polyphenols in $\mathrm{mg}$ GAE/100 $\mathrm{g}$ fresh product were determined by Folin Ciocalteu colorimetric method, where the results were given in gallic acid equivalent value (52).

\section{Determination of ascorbic acid content}

Vitamin C content was determined by redox titration using iodine solution following the method by Ciancaglini et al. (11).

\section{Determination of nitrate}

The nitrate content in lettuce leaves was measured based on the method by Kmecl et al. (29) using Segmented Flow Analyzer (AA II, Bran+Luebbe) at the wavelength of $540 \mathrm{~nm}$ after the reduction in copper coated cadmium column $\left(\mathrm{NO}_{3}{ }^{-}+2 \mathrm{e}^{-}\right.$( $\left.\mathrm{NO}_{2}{ }^{-}\right)$to form diazo compound

\section{Statistical analysis}

Data were subjected to one-way analysis of variance (ANOVA) at the confidence level $\mathrm{P} \leq 0.05$ using SPSS version 25 . 


\section{RESUITS AND DISCUSSION}

Effect of biostimulants on bioactive compounds of lettuce

Biostimulants are applied to plants in a small quantity in order to enhance growth and development in order to provide a better yield and quality, because it works as a material other than fertilizer $(2,53)$. According to our results, the bioactive compounds and nitrate is affected by treatments rather than varieties (Table 1-2). The highest total polyphenol content was measured in the treatment of
Willow extract + Bistep (80.64 mg/100g), while the lowest result was for the Bistep treatment $(55.60 \mathrm{mg} / 100 \mathrm{~g})$. Similar tendency was recorded for the Vitamin $\mathrm{C}$, the highest amount was detected for the plants treated with Willow + Bistep (7.28 mg/100g), while the lowest was for the control plants (4.88 $\mathrm{mg} / 100 \mathrm{~g}$ ). On the other hand, nitrate content was enough increased in the plants treated with Willow extract $(629.0 \mathrm{mg} / 100 \mathrm{~g})$ and the lowest amount was recorded in the control plants $(488.0 \mathrm{mg} / \mathrm{g})$.

Table 3. Effect of biostimulants treatments on bioactive compounds and nitrate content in the mean of lettuce varieties

\begin{tabular}{|c|c|c|c|}
\hline Treatments & $\begin{array}{c}\text { Total } \\
\text { polyphenols } \\
\text { (mg GAE } / 100 \mathrm{~g} \\
\text { product) }\end{array}$ & $\begin{array}{c}\text { Vitamin C } \\
\text { (mg/ 100 g } \\
\text { product) }\end{array}$ & Nitrate $(\mathrm{mg} / \mathrm{kg})$ \\
\hline & \multicolumn{3}{|c|}{ Mean+SD_ } \\
\hline Control & $55.85^{\mathrm{b}} \pm 1.38$ & $4.88^{c} \pm 0.05$ & $488.00^{b} \pm 11.32$ \\
\hline Willow & $59.41^{b} \pm 5.57$ & $5.30^{b} \pm 0.15$ & $692.00^{\mathrm{a}} \pm 2.57$ \\
\hline Bistep & $55.60^{b} \pm 3.54$ & $5.44^{b} \pm 0.37$ & $527.66^{b} \pm 61.03$ \\
\hline $\begin{array}{c}\text { Willow and } \\
\text { Bistep }\end{array}$ & $80.64^{a} \pm 3.05$ & $7.28^{a} \pm 0.09$ & $534.33^{b} \pm 20.63$ \\
\hline
\end{tabular}

Means within the same column followed by the same letter(s) are not significantly different at the probability level of $(p \leq 0.05)$ according to Tukey HSDa,b test Multiple Range Test In the mean of treatment, according to our measurements, it was not significant differences among the varieties (Table 3) for the bioactive compounds Table 4. Effect of different lettuce varieties on the bioactive compounds and nitrate content in the mean of treatments

\begin{tabular}{|cccc|}
\hline Varieties & $\begin{array}{c}\text { Total } \\
\text { polyphenols } \\
\text { (mg GAE / } \\
100 g \text { product) }\end{array}$ & $\begin{array}{c}\text { Vitamin C } \\
\text { (mg / 100 } \\
\text { g product) }\end{array}$ & Nitrate (mg/kg) \\
\hline & \multicolumn{3}{c|}{ Mean+SD } \\
King of May & $\mathbf{6 1 . 1 0}^{\mathrm{a}} \pm 14.29$ & $\mathbf{5 . 7 4}^{\mathrm{a}} \pm 1.13$ & $\mathbf{5 6 0 . 1 5}^{\mathrm{a}} \pm 91.39$ \\
Kobak & $\mathbf{6 3 . 2 2}^{\mathrm{a}} \pm 12.83$ & $\mathbf{5 . 6 5}^{\mathrm{a}} \pm 1.11$ & $546.75^{\mathrm{a}} \pm 99.8$ \\
Great Lakes & $\mathbf{6 4 . 3 0}^{\mathrm{a}} \pm 9.50$ & $\mathbf{5 . 8 0}^{\mathrm{a}} \pm 1.04$ & $\mathbf{5 7 4 . 9 5}^{\mathrm{a}} \pm 90.56$ \\
\hline
\end{tabular}

*Means within the same column followed by the same letter(s) are not significantly different at probability level $(p \leq 0.05)$ according to Tukey HSD ${ }^{a, b}$ test Multiple Range Test

Interaction effect of biostimulants and varieties on some bioactive compounds of lettuce: Polyphenols are important phytochemical substances to the human immune system (10). Vegetables and fruit are rich in polyphenols and flavonoids which are related with decreasing the risks of certain chronic diseases as cancer and cardiovascular diseases (22). The amount of antioxidant in plants relies on many factors such as stress which come mostly from insect attacks, fertilization and nutrient management $(52,42)$. Polyphenols in the lettuce leaves are shown in Figure 1. The content is varied from variety and treatment to another. All of varieties recorded a significant difference compare to Willow+Bistep treatment, while the lowest total polyphenol was recorded for the control plants. Lettuce varieties were almost the same in their reaction to the treatments.

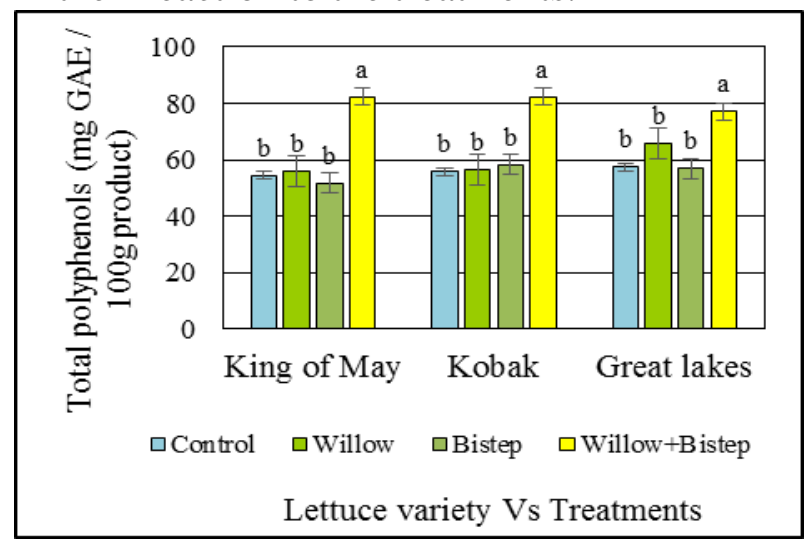

Figure 1. Interaction effect of varieties and treatments on total polyphenol content in lettuce leaves 
*Means within the same column followed by the same letter(s) are not significantly different at probability level $(p \leq 0.05)$ according to Tukey HSD $^{a, b}$ test Multiple Range Test

Interaction effect of treatments and varieties on vitamin $C(\mathbf{m g} / \mathbf{1 0 0 g})$ in lettuce leaves: Vitamins are essential nutrient for metabolism of the human body $(22,1)$. It is a daily essentiality nutrient which leads to reduce some diseases like scurvy (37), carcinogenic illnesses, protecting bones becoming fragile through taking part in the collagen formation as well as swollen gums and bleed (1). To achieve a healthy body in adults, 30 to $110 \mathrm{mg} /$ day of the intake of vitamin $\mathrm{C}$ is recommended $(21,31)$. Lettuce is not considered as a very high source of vitamin $\mathrm{C}$, however, it is advantages to eat row, this preserves its nutritive value because vitamin $\mathrm{C}$ is unstable and degrades at $50{ }^{\circ} \mathrm{C}$ $(1,48)$. Results from Aćamović-Đoković (1) show the amount of vitamin $\mathrm{C}$ in lettuce leaves ranges from 3.8 to $9.6 \mathrm{mg} / 100 \mathrm{~g}$. Figure 2 indicates the value of vitamin $\mathrm{C}$ in $\mathrm{mg} / 100 \mathrm{~g}$. This amount was influenced mainly by the combination of biostimulants in different lettuce varieties. All the treatments were significantly different in comparison to the control. The highest result $(7.29,7.24$ and 7.40 $\mathrm{mg} / 100 \mathrm{~g}$ ) was for the varieties (Kobak, Great Lakes and King of May) treated with Willow+Bistep, followed by Willow extract and Bistep, while the lowest result for all three varieties was in the control. The greener leaves of Great Lakes variety recorded the higher vitamin $\mathrm{C}$ content comparing to other varieties which have green-yellow leaves. This result is agreed to the result by Aćamović-Đoković at al. (1), where they found that the greener lettuce leaf colour of Levistro variety recorded the greater vitamin $\mathrm{C}$ content $(9.60 \mathrm{mg} / 100 \mathrm{~g})$, comparing to the red leaf variety Murai (3.50 $\mathrm{mg} / 100 \mathrm{~g})$.

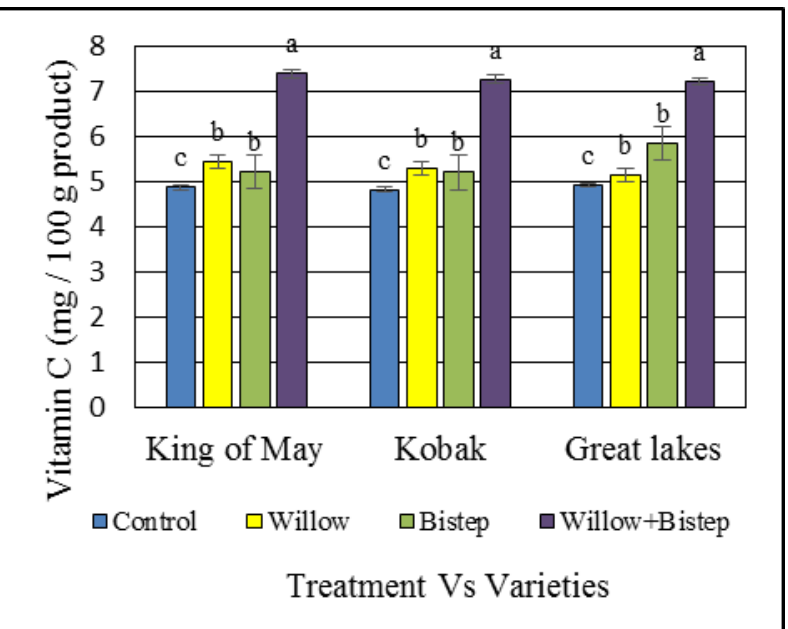

Figure 2. Interaction effect of varieties and treatments on Vitamin $C$ content in lettuce leaves

* Means within the same column followed by the same letter(s) are not significantly different at probability level $(p \leq 0.05)$ according to Tukey HSD $^{a, b}$ test Multiple Range Test

Interaction effect of the treatments and varieties on nitrate content in lettuce leaves

Wang et al. (31) indicated very large interval of content for nitrate in lettuce ranged between $(123-2678 \mathrm{mg} / \mathrm{kg}$ fresh weight) and nitrite (0.08-2.15 mg/kg fresh weight). Santamaria (44) has classified the vegetables and stated that lettuce as one of the very high nitrate rich species together with celery, spinach and rocket. It is essential to highlight the nitrate content of the studied lettuce cultivars in the Figure 3. Nitrate accumulation was mostly affected by the treatments. Significant difference was recorded in the plants of all the three varieties treated with Willow extracts compared to other treatments. It was not detected significant difference by other treatments. The highest nitrate content was recorded for the Willow treatment in Kobak variety $(695 \mathrm{mg} / \mathrm{kg})$ followed by Great Lakes and King of May (691 and $690 \mathrm{mg} / \mathrm{kg}$, respectively), while the lowest nitrate level was in the King of May variety treated with Bistep (492 mg/kg), furthermore in Kobak and Great Lakes by control treatment (478 and 486 $\mathrm{mg} / \mathrm{kg}$, respectively).

Interaction effect of the treatments and varieties on nitrate content in lettuce leaves Wang et al. (51) indicated very large interval of content for nitrate in lettuce ranged between $(123-2678 \mathrm{mg} / \mathrm{kg}$ fresh weight) and nitrite $(0.08-2.15 \mathrm{mg} / \mathrm{kg}$ fresh weight). Santamaria (44) has classified the vegetables and stated 
that lettuce as one of the very high nitrate rich species together with celery, spinach and rocket. It is essential to highlight the nitrate content of the studied lettuce cultivars in the Figure 3. Nitrate accumulation was mostly affected by the treatments. Significant difference was recorded in the plants of all the three varieties treated with Willow extracts compared to other treatments. It was not detected significant difference by other treatments. The highest nitrate content was recorded for the Willow treatment in Kobak variety $(695 \mathrm{mg} / \mathrm{kg})$ followed by Great Lakes and King of May (691 and $690 \mathrm{mg} / \mathrm{kg}$, respectively), while the lowest nitrate level was in the King of May variety treated with Bistep (492 mg/kg), furthermore in Kobak and Great Lakes by control treatment (478 and 486 $\mathrm{mg} / \mathrm{kg}$, respectively).

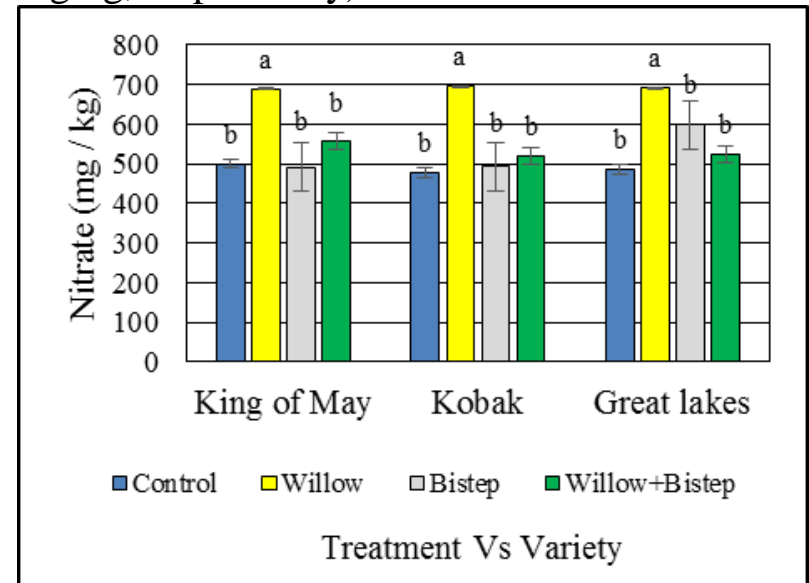

Figure 3. Interaction effect of varieties and treatments on nitrate accumulation in lettuce leaves

*Means within the same column followed by the same letter(s) are not significantly different at probability level $(p \leq 0.05)$ according to Tukey HSD ${ }^{a, b}$ test Multiple Range Test

\section{Conclusion}

There was not a steady difference in bioactive and nitrate content among the lettuce varieties, the differences were only recorded with the effect of the treatments on the plants rather than the varieties. According to our results, the recommended Bistep concentration (0.5\%) was useful for improving bioactive compound in lettuce leaf without increasing the nitrate level. Also, the use of Willow bark extract improved the total polyphenol and vitamin $\mathrm{C}$ content of lettuce, but as a side effect have caused $28-31 \%$ higher nitrate content compared to the control although the amount is still lower than the limits set by the
European Commission Regulation. Though, in our experiment, the best result was realized by the combination of Bistep + Willow extract. So that, we can conclude that Willow extract is an excellent substance with other biostimulants, like Bistep to improve the quality of lettuce in organic farming.

\section{REFRENCES}

1. Aćamović-Đoković G, Pavlović R, Mladenović J, Đurić M. Vitamin C content of different types of lettuce varieties. Acta Agric Serbica. 2011;16(32):83-9.

2. Ali M, CHENG Z hui, Hayat S, Ahmad H, Ghani MI, LIU T. Foliar spraying of aqueous garlic bulb extract stimulates growth and antioxidant enzyme activity in eggplant (Solanum melongena L.). J Integr Agric [Internet]. 2019;18(5):1001-13. Available from: $\quad$ http://dx.doi.org/10.1016/S20953119(18)62129-X

3. Andreu V, Levert A, Amiot A, Cousin A, Aveline N, Bertrand C. Chemical composition and antifungal activity of plant extracts traditionally used in organic and biodynamic farming. Environ Sci Pollut Res. 2018;25(30):29971-82.

4. Archer DL. Evidence that ingested nitrate and nitrite are beneficial to health. J Food Prot. 2002;65(5):872-5.

5. Authority European Food Safety. Nitrate in vegetables. EFSA Journal. 2008;68:91-79.

6. Beresford SA. Is nitrate in drinking water associated with gastric cancer in the urban UK? Int J Epidemiol. 1985;14:57-63

7. Brkić D, Bošnir J, Bevardi M, Bošković AG, Miloš S, Lasić D, et al. Nitrate in leafy green vegetables and estimated intake. African J Tradit Complement Altern Med. 2017;14(3):31-41.

8. Boink A, Speijers G. Health effects of nitrates and nitrites, a review. Acta Hortic. 2001;563:29-36.

9. Blom-zandstra M. Nitrate accumulation in vegetables and its relationship to quality. Ann Appl Biol. 1989;115(3):553-61

10. Biesiada A, Tomczak A. Biotic and abiotic factors affecting the content of the chosen antioxidant compounds in vegetables. Veg Crop Res Bull. 2012;76(1):55-78.

11. Ciancaglini P, Santos HL, Daghastanli KRP, Thedei G. Using a classical method of vitamin $C$ quantification as a tool for 
discussion of its role in the body. Biochem Mol Biol Educ. 2001;29(3):110-4.

12. Commission Implementing, Regulation (EU). Approving the basic substance Salix spp. cortex. No 2015/1107 of 8 July 2015 [Internet]. Vol. OJ L 181. 2015. p. 72-4. Available from: https://eurlex.europa.eu/legal-

content/EN/TXT/PDF/?uri=CELEX:32015R1

\section{$107 \&$ from $=\mathrm{LV}$}

13. Cavaiuolo M, Ferrante A. Nitrates and glucosinolates as strong determinants of the nutritional quality in rocket leafy salads. Nutrients. 2014;6(4):1519-38.

14. Diplock AT, Charuleux J-L, Crozier-Willi G, Kok FJ, Rice-Evans C, Roberfroid M, et al. Functional food science and defence against reactive oxidative species. $\mathrm{Br} \mathrm{J}$ Nutr. 1998;80(S1):S77-112.

15. Du S ting, Zhang Y song, and Lin $\mathrm{X}$ yong. Accumulation of Nitrate in Vegetables and Its Possible Implications to Human Health. Agric Sci China. 2007;6(10):1246-55.

16. Du Jardin P. Plant biostimulants: Definition, concept, main categories and regulation. Sci Hortic (Amsterdam) [Internet]. 2015;196:3-14. Available from: http://dx.doi.org/10.1016/j.scienta.2015.09.021 17. Dong C, Wang G, Du M, Niu C, Zhang P, Zhang $\mathrm{X}$, et al. Biostimulants promote plant vigor of tomato and strawberry after transplanting. Sci Hortic (Amsterdam). 2020;267(January).

18. Deniau MG, Bonafos $\mathrm{R}$, Chovelon $\mathrm{M}$, Parvaud C-E, Furet A, Bertrand C and, et al. Willow Extract (Salix cortex), a Basic Substance of Agronomical Interests. Int J Bioresource Stress Manag. 2019;10(4):408-18.

19. Forman D, Al-Dabbagh S, Doll R. Nitrates, nitrites and gastric cancer in Great Britain. Nature. 1985;313(6004):620-5.

20. Gangolli SD, P van den B, Feron V JC, J K, G S, B S, et al. Nitrate, nitrite and N-nitroso compounds in human bladder cancer associated with schistosomiasis [2]. Eur J Pharmacol Env Toxicol Pharmacol Sect. 1994;1(38):292.

21. Halliwell B. Vitamin C and genomic stability. Mutat Res - Fundam Mol Mech Mutagen. 2001;475(1-2):29-35.

22. Hancock RD, Viola R. Improving the nutritional value of crops through enhancement of L-ascorbic acid (vitamin C) content: Rationale and biotechnological opportunities. J Agric Food Chem. 2005;53(13):5248-57.

23. Hussain H, Badawy A, Elshazly A, Elsayed A, Krohn K, Riaz M, et al. Chemical constituents and antimicrobial activity of Salix subserrata. Rec Nat Prod. 2011;5(2):133-7.

24. Hord NG, Tang Y, Bryan NS. Food sources of nitrates and nitrites: The physiologic context for potential health benefits. Am J Clin Nutr. 2009;90(1):1-10.

25. Harte J, Holdren C, Schneider R, Shirley C. Toxics A to $\mathrm{Z}$ : A guide to everyday pollution hazards. Univ of California Press.; 1991.

26. Hu FB. Dietary pattern analysis: A new direction in nutritional epidemiology. Curr Opin Lipidol. 2002;13(1):3-9.

27. Iammarino $\mathrm{M}$, Di Taranto $\mathrm{A}$, Cristino $\mathrm{M}$. Monitoring of nitrites and nitrates levels in leafy vegetables (spinach and lettuce): A contribution to risk assessment. J Sci Food Agric. 2014;94(4):773-8.

28. Kaur C, Kapoor HC. Anti-oxidant activity and total phenolic content of some Asian vegetables. Int $\mathbf{J}$ Food Sci Technol. 2012;37(2):153-61.

29. Kmecl V, Knap T, Žnidarčič D. Evaluation of the nitrate and nitrite content of vegetables commonly grown in Slovenia. Ital J Agron. 2007;12(2).

30. Luo J, Sun S, Jia L, Chen W, Shen Q. The mechanism of nitrate accumulation in pakchoi [Brassica campestris L.ssp. Chinensis(L.)]. Plant Soil. 2006;282(12):291-300.

31. Levine $\mathrm{M}$, Wang $\mathrm{Y}$, Padayatty SJ, Morrow J. A new recommended dietary allowance of vitamin $\mathrm{C}$ for healthy young women. Proc Natl Acad Sci U S A. 2001;98(17):9842-6.

32. Milivojrvic J, Bogdanovic-Pristov J, and Maksimovic V. Phenolic compounds and vitamin $C$ as sources of antioxidant activity in black currant fruit ( Ribes. Acta Agric Serbica. 2010;XV(29):3-10.

33. Madhavi DL, Deshpande SS, Salunkhe DK. Food Antioxidants: Technological, Toxicological, Health Perspective. New York: Marcel Dekker; 1996. 
34. McKnight GM, Duncan CW, Leifert C, Golden $\mathrm{MH}$. Dietary nitrate in man: friend or foe? Br J Nutr. 1999;81(5):349-58.

35. Mola I di, Ottaiano L, Cozzolino E, Senatore M, Giordano M, El-Nakhel C, et al. Plant-based biostimulants influence the agronomical, physiological, and qualitative responses of baby rocket leaves under diverse nitrogen conditions. Plants. 2019;8(11):1-15.

36. Marchand PA. Basic substances under EC 1107/2009 phytochemical regulation: Experience with non-biocide and food products as biorationals. J Plant Prot Res. 2016;56(3):312-8.

37. Naidu KA. Vitamin C in human health and disease is still a mystery? An overview. Nutr J. 2003;2(7):1-10.

38. National Research Council. Nitrate and nitrite in drinking water. National Academies Press. In: Nitrate and nitrite in drinking water. 1995. p. 1-64.

39. Ördögh M, Beregi Z, Tillyné Mándy A. The effect of different biostimulators on morphological and biochemical parameters of micropropagated Hosta 'Gold Drop'. Int J Hortic Sci. 2019;25(1-2.):22-9.

40. Qiu W, Wang Z, Huang C, Chen B, Yang R. Nitrate accumulation in leafy vegetables and its relationship with water. $\mathbf{J}$ Soil Sci Plant Nutr. 2014;14(4):761-8.

41. Pavlou GC, Ehaliotis CD, Kavvadias VA. Effect of organic and inorganic fertilizers applied during successive crop seasons on growth and nitrate accumulation in lettuce. Sci Hortic (Amsterdam). 2007;111(4):319-25.

42. Rimmer DL. Free radicals, antioxidants, and soil organic matter recalcitrance. Eur J Soil Sci. 2006;57(2):91-4.

43. Speijers GJA. Nitrate, in Toxicological evaluation of certain food additives and contaminants in food, , Food Additives Series 35,. Geneva,; 1996.

44. Santamaria P. Nitrate in vegetables: toxicity, content, intake and $\mathrm{EC}$ regulation. J Sci Food Agric. 2006;86(1):10-7

45. Sharma HSS, Fleming C, Selby C, Rao JR, Martin T. Plant biostimulants: A review on the processing of macroalgae and use of extracts for crop management to reduce abiotic and biotic stresses. J Appl Phycol. 2014;26(1):465-90.

46. Singleton VL, Orthofer R, LamuelaRaventós RM. [14] Analysis of total phenols and other oxidation substrates and antioxidants by means of folin-ciocalteu reagent. Methods Enzymol. 1999;299:152-78.

47. Steinmetz KA, Potter JD. Vegetables, fruit, and cancer prevention: A review. J Am Diet Assoc. 1996;96(10):1027-39.

48. Vaughn RH, Marsh GL. The Chemistry and Technology of Food and Food Products. Volume II (Jacobs, Morris B., ed.). J Chem Educ [Internet]. 1945 May 1;22(5):260. Available from: https://doi.org/10.1021/ed022p260.1

49. Wong CC, Li H Bin, Cheng KW, Chen F. A systematic survey of antioxidant activity of 30 Chinese medicinal plants using the ferric reducing antioxidant power assay. Food Chem. 2006;97(4):705-11.

50. WHO. Global Strategy on Diet, Physical Activity and Health: Promoting fruit and vegetable consumption around the world [Internet]. 2003. Available from: https://www.who.int/dietphysicalactivity/fruit/ en

51. Wang ZHTX, Wei YS, Li SX. Nitrate accumulation and its regulation by nutrient management in vegetables. In: Balanceable Fertilization and High Quality Vegetables Continual Production. Press, Beijing. (in Chinese); 2000.

52. Young JE, Zhao X, Carey EE, Welti R, Yang SS, Wang W. Phytochemical phenolics in organically grown vegetables. Mol Nutr Food Res. 2005;49(12):1136-42.

53. Zhang, X., Schmidt, R.E. The impact of growth regulators on alpha-tocopherol status of water-stressed Poa pratensis L. Int Turfgrass Soc Res J. 1997;8:1364-2137. 